\title{
A New Historicist Reading of Selected Children's Nursery Rhymes
}

\author{
Dr. Mohammad Ahmad Mostafa Al-Leithy \\ Assistant Professor of English Literature \\ Faculty of Arts - Arish University \\ Department of English
}

\begin{abstract}
The aim of this study is to provide a New Historicist reading of British children's nursery rhymes. The paper aims at investigating the different factors that went into the making up of such rhymes. These include the personal, the social, the political, the religious and the economic aspects underlying selected nursery rhymes side by side with the literary value of texts of the rhymes themselves.

The poems selected for study will be investigated through the lenses of New Historicism because of the importance the latter gives to the text's backgrounds. The paper tries to relocate the rhymes properly on the map of English literature. "Baa, Baa, Black Sheep", "Jack Sprat", "When Adam Delved", "Mary, Mary, Quite Contrary" and "Three Blind Mice" are among the poems discussed in this study.

One of the important conclusions of this study is that many nursery rhymes were originally commoners' verses, composed to address and express the common people's cares and worries. The apparent simplicity and naivety of the poems are guises under which commoners concealed their ideas. This made the poems easy to memorise since the majority of the people were illiterate.
\end{abstract}


مجلة وادي النيل للار اسات والبحوث الإسانية والاجتماعية والتربوية (مجلة علمية محكمة)

(ISSN : 2536 - 9555)

\section{قراءةٌٌ لمختاراتٍ من أناشيدٍ الأطفالِ من منظورِ التاريخيةِ الجديدةِ}

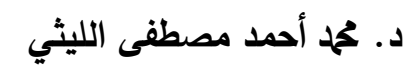

أستاذ مساعد - بقسم اللغة الإنجليزية وآدابها- كلية الآداب- جامعة العريش

ملخص البحث

كثيرٌ من ينظرونَ لأدب الأطفالِ عامة وأناشيدٍ الأطفالِ البريطانيةِ خاصةِ

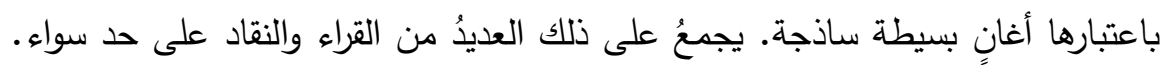

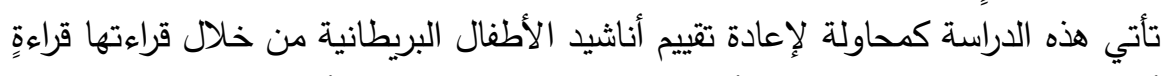

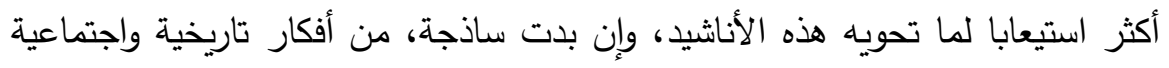

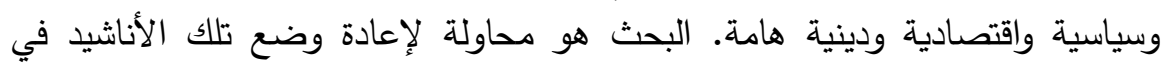
مكانها ومكانتها الصحيحين على خارطة الأدب.

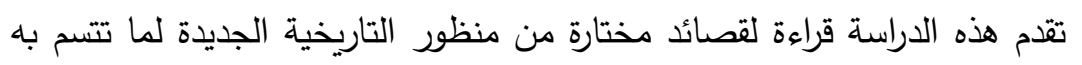

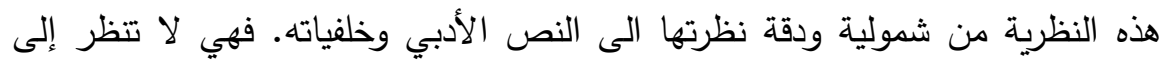

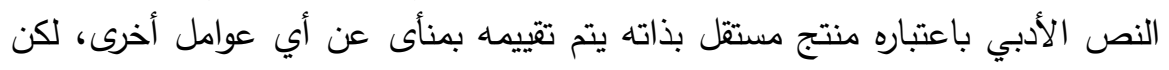

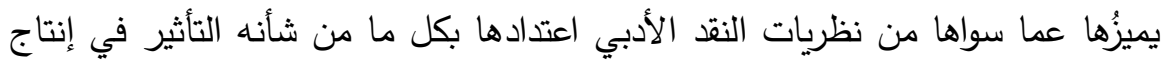

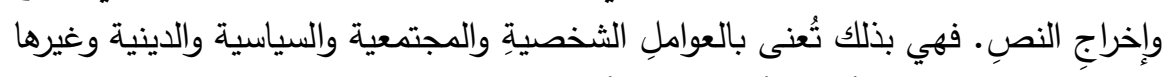

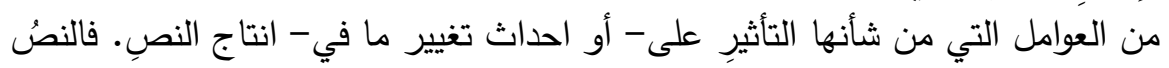

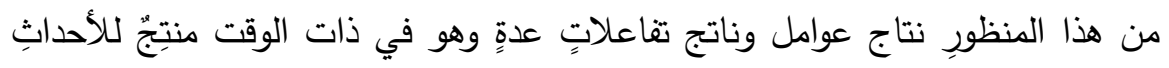

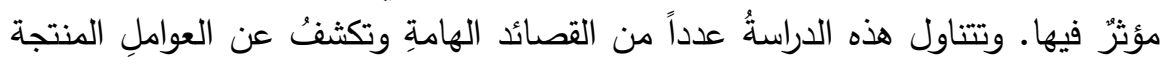

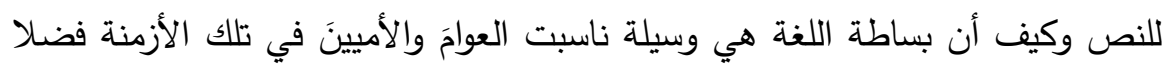

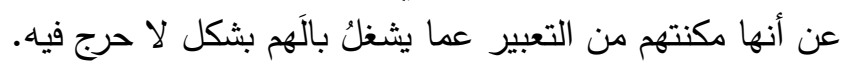

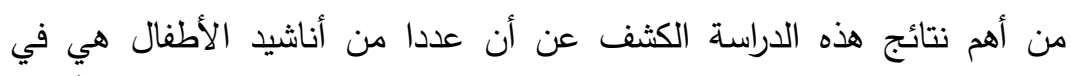

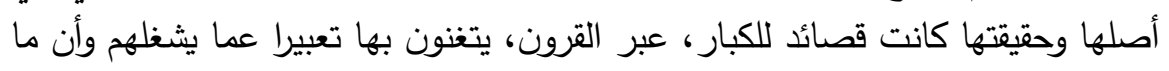

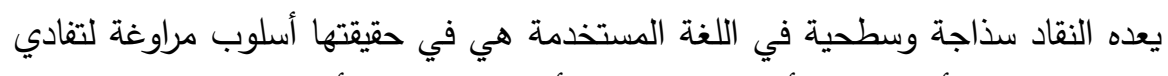

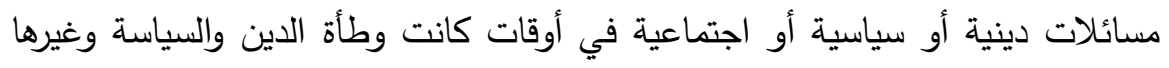

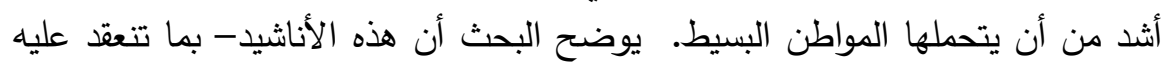

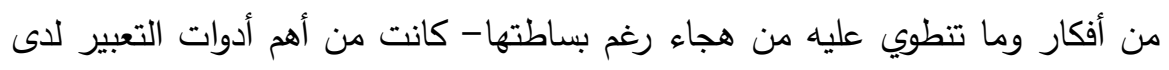

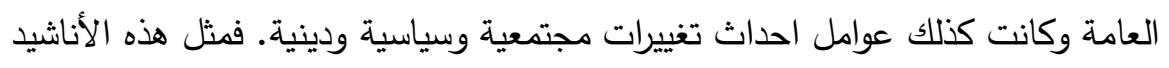
يمكن وصفها بأنها أشعار العامة في تلك الأزمنة. 
A New Historicist Reading of Selected Children's Nursery Rhymes

Dr. Mohammad Ahmad Mostafa Al-Leithy

مجلة وادي النيل للاراسات والبحوث الإنسانية والاجتماعية والتريوية (مجلة علمية محكمة)

A New Historicist Reading of Selected Children's Nursery Rhymes

I

A child is what you make rather than what you want. Centuries ago, England got to realise this fact and gave special care to childhood as a phase. In so doing, it was influenced, among other things, by the writings and views of such important thinkers and philosophers as John Locke (1632-1704) and Jean-Jack Rosseau (1712-1778) who contributed importantly to European awareness of the importance of childhood and that childhood should be dealt with as "a period distinct from infancy and adulthood" (Maybin 56-57). Special attention has, thus, been paid to what has become known as children's literature. At the core of such a body known as children's literature lies a corpus of rhymes known as nursery rhymes. Such rhymes are elemental to the construction of the British childhood identity. Commonly referred to as nursery rhymes, these are a myriad of poems that "construct and reconstruct" the "worlds" of such children (Rogers). It should be noted that the words rhyme, poem and lyric have been used interchangeably to refer to the rhymes; a rhyme is a poem, after all (Baldick 233).

This paper has three sections the first of which defines nursery rhymes, highlight their influence, states the aim of the paper and poses the questions the study will respond to. Section II introduces New Historicism, the critical approach through which these poems will be investigated. Section III will get down to a number of the important nursery rhymes through the lenses of New Historicism. The section discusses some of the best-known rhymes such as "Baa, Baa, Black Sheep", "Jack Sprat", "When Adam Delved", "Remember, Remember the Fifth of November", "Ring Around the Rosy", "Mary, Mary, Quite Contrary", "Three Blind Mice" and "Oranges and Lemons".

Nursery rhymes are "short songs and verses often read or sung to, or by, young children. Generally, these verses are 
anonymous, although the term nursery rhyme has also been applied to works written by known authors. Many familiar nursery rhymes are centuries old and originated as part of a long oral tradition" (oxfordbibliographies). The American Heritage Dictionary of the English Language defines the term as, "a short, rhymed poem or tale for children" (American 1243). The use of the term, as Maiti points out, goes back to 1843 (28). The word 'nursery' here refers to the place where such poems are commonly sung. The poems are, however, by no means restricted to nurseries; they are also sung at home by parents to their children and some of these songs are lullabies, "the whisper-soft of bedtime" (Rogers), sung to children when put to sleep. They awaken a sense of musicality and love of words that kindle a child's mind and sensations:

I had many favourite poems as a young child, and I was introduced to most of them by my mother. She was of a generation accustomed to memorise poetry as part of their nursery and school education, and would recite snatches of them around the house, as an accompaniment to domestic dramas. She also read to us for many years at bedtime which is why even today when I read or hear the poem, I always hear it in her clear edgy voice. I also know it by heart, largely because of hearing it in this way from an early age. (Children's Literature 118)

Nancy Crosby acknowledges that in Britain, at quite an early age, children get accustomed to listening to adults singing nursery rhymes to them, and adds that the sounds and rhythm of the rhymes as well as the melody of language, "bring pleasurable sensations even before [a child] understands their meaning". That is a time when children are "captivated by the sound of poetry" (Rogers). Dolezalova, in his turn, asserts, there is almost nobody who would not be able to "recite at least a few nursery rhymes" even though many people would not really know what the rhymes really meant or where they came from (5).

Despite the fact that scholars in different fields of knowledge, linguistics, anthropology, education and sociology, 


\title{
A New Historicist Reading of Selected Children's Nursery Rhymes Dr. Mohammad Ahmad Mostafa Al-Leithy
}

\author{
مجلة وادي النيل للاراسات والبحوث الإنسانية والاجتماعية و التربوية (مجلة علمية محكمة)
}

among others, have availed themselves greatly of nursery rhymes, literary critics and scholars have comparatively paid only quite scant attention to these rhymes. The reason behind this is that nursery rhymes have been considered of little literary value, as will be discussed in more detail later in the paper. Few literary critics and scholars, it should be acknowledged, were keen enough to delve deeper and discover the real value of these rhymes. Abhik Maiti asserts that nursery rhymes are "an elemental part of literature" (102) and Teng acknowledges that "several unexplored issues remain to be examined" (5). The importance of evaluating these rhymes further emanates from the fact that "education of young children is shaped by political drivers that emphasise academic and standardized achievement" (Marsh 9).

The aim of this study, as the title promises, is to provide a New Historicist reading of British children's nursery rhymes. The paper aims at exploring and investigating the different factors that went into the making up of such rhymes. Therefore, it is important to explore and investigate the personal, the social, the political, the religious and the economic aspects underlying selected nursery rhymes side by side with the literary value of texts of the rhymes themselves. From the start, it should be noted that these elements are hard to separate from one another. The New Historicist approach will be adopted as it takes to its focal interest the different elements that contribute to the making of a literary text and, at the same time, how, in its turn, the literary text reflects the milieu of its times. This critical approach, thus, transcends the limits of the text and probes into the backgrounds lying behind it. It should be noted, however, that New Historicism is not yet a complete theory; it is a set of assumptions, but without a clear-cut, crystalised methodology, as its founders admit (Lodge 495).

The paper will respond to the following questions: how are literary and non-literary texts important for proper understanding of nursery rhymes? To what extent do literary and non-literary texts, as approached through New Historicism, integrate to unveil the meaning of nursery rhymes together with the spirit of the age that produced the rhymes? 
مجلة وادي النيل للاراسات والبحوث الإنسانية والاجتماعية والتربوية (مجلة علمية محكمة)

(ISSN : 2536 - 9555)

To start with, the subtlety underlying nursery rhymes can well escape the attention of readers and critics alike. Many nursery rhymes have secret, hidden meanings, and allude, among other things, to important social, political and religious figures and events. The rhymes should, therefore, be reread and reassessed. Political orientations loom large in many of these poems; a good number of them is, after all, mainly concerned with powerful figures of the state and the decisions they made. This adds to the suitability of the critical approach adopted. It is believed that through unveiling the origins of the elements that comprise the rhymes, complicated as they are, the rhymes can be better understood and valued. More often than not, such elements intertwine and, consequently, delineations seem to blur and vanish. At different points, it should be noted, politics in nursery rhymes inevitably converges with some other domains foremost among which are economics, religion and history.

Despite their importance in the formation of British childhood identity, English nursery rhymes have been devalued and have often been looked at as trivial, "nonsensical" (Maiti 50), naïve sound games and nothingnesses by many literary critics. June Factor calls them "children's verbal lore" (Children's Voices). At their best, as observed by some readers and critics, nursery rhymes are not anything more than sheer verbal, rhetoric exercises void of real literary value or weiwghty ideas. They have, thus, been slighted and taken as a low literary genre appropriate only for children. One of the main reasons why such rhymes have been undervalued is that the backgrounds to the rhymes were not really explored and, hence, a true comprehension of the rhymes was not reached.

\section{II}

\section{New Historicism: A Background}

Due to its macroscopic lenses of looking at literary texts, New Historicism is believed to be more appropriately applicable as an approach of literary criticism to nursey rhymes. Since its emergence at the beginning of the 1980s up to the present, New Historicism has remarkably gained more grounds on the literary 


\section{A New Historicist Reading of Selected Children's Nursery Rhymes Dr. Mohammad Ahmad Mostafa Al-Leithy}

مجلة وادي النيل للار اسات و البحوث الإنسانية والاجتماعية والتربوية (مجلة علمية محكمة)

and the critical arenas. Hence, prior to coming to grips with the rhymes, it is appropriate at this point to introduce New Historicism briefly. Essential to a true understanding of New Historicism are the assumptions of its pioneering figures, such as Stephen Greenblatt (b. 1943 ), Catherine Gallagher (b. 1945) and Michael Foucault (1926-1984). One of the most important assumptions, as Jeremy Hawthorn asserts, is that the New Historicist "has as much to say about the reading of the texts as about their composition" (236). The assumptions include, but are not limited to, the intricacies of the biographical, political, religious and economic supremacy and dominance of those in power and how laws and decisions decreed by authorities of the state affect common folks.

New Historicism, it is worth remarking, is more concerned with the questions of "power and culture (especially the messy commingling of the social and the cultural or of the supposedly autonomous self and the cultural/political institutions that in fact produce that self" (cla.purdue). Felluga stresses New Historicism's association with authority and the dominance of power and sees this to be a main point that distinguishes this critical approach from others, such as Cultural Materialism (purdue.edu). Thus, whereas the former, New Historicism

tend[s] to concentrate on those at the top of the social hierarchy (i.e. the church, the monarchy, the upperclasses), [the latter]... tend[s] to concentrate on those at the bottom of the social hierarchy (the lowerclasses, women, and other marginalized peoples)... [It] tend[s] to draw on the disciplines of political science and anthropology given their interest in governments, institutions, and culture... (la.purdue)

To New Historicists, the text does not exist in vacuum, detachedly independent from backgrounds. Indeed, such spectrumlike backgrounds, to Greenblatt and other adherents of the theory, are considered as essential to understanding a literary text as the text itself. A New Historicist looks at a text as the ultimate outcome, a totality and crystalisation, of a multitude of non-literary 
elements that jointly contributed to the production of a literary text. Barry says that in New Historicist readings of literary texts "literary and non-literary texts are given equal weight and constantly inform and interrogate each other" (172). He, further, asserts that New Historicists read literary texts in the light of nonliterary texts (179). A New Historicist, thus, assumes the indispensability of the paratextual resources and vistas in appreciating a literary text. The relationship between the literary text and such backgrounds, dubbed "poetics of culture" by S. Greenblatt (Lodge 495), can be looked at as mutual in more than one respect: both produce and are produced by the other and, consequently, both are important to proper understanding of the other; "When Adam Delved" rhyme is a good example in this respect. Stephen Greenblatt refers to this mutuality as "the historicity of texts and the textuality of history" (Hawthorn 236).

What essentially distinguishes New Historicism as a critical stance from all other critical approaches is the wider scope that incorporates the variety of factors and elements that contribute to the making of a text. Thus, while (old) Historicism, for instance, insists on seeing a literary text as the production, more than anything else, of the historical events of its own time, New Historicism goes beyond the sheer historical to discover and examine the more comprehensive prism of the social, the local, the personal together with other plaits that collectively generate the text. In so doing, it unearths the granules and particles, of little importance as they may sound at first, that collaboratively form the mosaic of a text's background. Such, so to speak, paratextual elements, "para" meaning beside, eventually turn out to provide avenues essential to understanding a text. Paratextual nuances and niceties are, thus, important to New Historicists since they look at the text to be a production of the totality of such catalyctical elements that permeate the textile of a text and which must, therefore, be considered side by side with the text itself.

A text cannot, consequently, stand on its own, apart from its contextual considerations. Advocates of this theory believe that 
A New Historicist Reading of Selected Children's Nursery Rhymes

Dr. Mohammad Ahmad Mostafa Al-Leithy

مجلة وادي النيل للاراسات و البحوث الإنسانية والاجتماعية و التريوية (مجلة علمية محكمة)

"every facet of reality is textualised" (Barry 179). Such "cotext[s]", to use Barry's word, can enable the reader to reexperience, and better assess, the "moment" the text was written by summoning the contexts and the processes that empowered and accompanied the formation and the production of the text (Barry 172). This makes of the text a true reflection of the true spirit of its times, i. e. zeitgeist.

\section{III}

One of the most popular nursery rhymes, "Baa, Baa, Black Sheep" teems with social, economic and political implications. The rhyme implicitly, though discretely suggests social discontent, and unemployment. While some critics believe that the poem criticises King Edward I's reign (1272-1307) others believe it refers to King Edward II's (1307-1327). Either way, this adds to the importance of the poem since the English people suffered greatly under the rule of both monarchs. Both kings, it is worth noting, belonged to the Plantagenet family, from French origins, that ruled England from 1154 to 1485 . As one critic observes, "many of the words and nursery rhymes were used to parody the royal and political events of the day" (rhymes.org). Critics agree, however, that the rhyme criticises lack of regal attention to the suffering of the farmers and wool workers that got negatively affected by important authorial decisions of the time. The poem reads:

Baa, baa, black sheep,

Have you any wool?

Yes sir, yes sir,

Three bags full.

One for the master,

One for the dame,

And one for the little boy

Who lives down the lane. (rhymes.org)

The diction of the poem is worth considering. The words "master" and "dame" are set in opposition to the word "boy". The first word can refer to the king and the second to nobility while the third refers to common folks. One of the important things to note 
مجلة وادي النيل للاراسات والبحوث الإنسانية والاجتماعية والتربوية (مجلة علمية محكمة)

(ISSN : 2536 - 9555)

about this rhyme is that it suggests that wool, standing for the wealth and natural resources of the country, is divided into three thirds: one for the king, another for the nobility and a third for the entire people of the country. For long periods of its history, nearly from the twelfth to the nineteenth centuries, England depended greatly on wool trade and products. English wool is known to be one of the best kinds of wool all around the world. Frank Langrish asserts that it is "unique wool" (1) with "unique characteristics" (10). Such is one of the facts English children should realise about their country.

One important inference of the poem is that it anticipates strikes as can be elicited from the sheep's reply that it has "Three bags full" of wool, a hint at the idea that wool is now thick and heavy for not having been sheared for a long time, which, in itself, suggests lack of work on the farmers' part. The phrase, thus, reveals social discontent. This can, thus, be a precursor of a forthcoming reaction on the farmers' part to decisions that affected their livelihood negatively. Significantly, the last line tells readers about the poor lane and the deplorable state the "little boy" lives in. The word "down" is employed deliberately, instead of in, to speak of the humiliating life poor commoners led and to criticise the social hierarchy and expose the suffering of the lower class.

The poem is said to criticise King Edward I's 1275 decision of imposing taxes on all wool exports, industries and products. Katherine E. Thomas, in The Real Personages of Mother Goose (1930), suggested the rhyme referred to resentment at the heavy taxation on wool and reflected on the magnitude of this little ostensibly naïve poem as she explains that

"Baa, Baa, Black Sheep!" arose the people's cry throughout the land. To further add to the discontent in the reign of...the abominably low wage everywhere given was paid out in the base coin... The price of foodstuffs rising, the result was a general revolt at Exeter...men formed a besieging party and Ket the Tanner, seated beneath an oak-tree at Norfolk, laid down the law to the "gentry" ere his 
A New Historicist Reading of Selected Children's Nursery Rhymes

Dr. Mohammad Ahmad Mostafa Al-Leithy

مجلة وادي النيل للار اسات و البحوث الإنسانية والاجتماعية والتربوية (مجلة علمية محكمة)

short-lived triumph culminated in his capture and hanging by the Earl of Warwick. (archive.org)

Deplorable economic circumstances of the time helped create the lines and the lines, in their turn, instigated and prompted reactions.

Other critics that believe this rhyme refers to King Edward II's reign see that the rhyme implies a subtle complaint of the authority's decision of encouraging of "Flemish weavers and cloth dyers to improve the quality of the final English products" (rhymes.org). The advent of such Flemish workers to England at the time affected the work of the English wool weavers so negatively that English weavers almost went on a strike at the time. The rhyme is, thus, an undercover complaint of King Edward II's encouraging of "Flemish weavers and cloth dyers to improve the quality of the final English products" (rhymes.org).

"Baa, Baa, Black Sheep" sounded loudest in London about the inner court of the ancient houses still standing in High Holborn. There sheep from all over the kingdom were penned and sheared in such vast numbers as to constitute this the wool mart of England. (archive.org)

Interestingly, and of great significance to this reading of the rhyme, the use of the word "black" to describe the sheep has attracted the attention of some critics who assert that the word has racial connotations. A lot of controversy, in Britain and Australia, has been aroused, especially in media, accusing the poem of being race biased. Many critics have interpreted the word as disparaging of the black. This led some nursery schools to substitute "Black" with other adjectives such as sad, hopping or pink. Such considerations are important to this New Historicist reading of the rhyme. This interference is known as "political correctness" (mothergeek.co), a term that refers to modifying language or policies to avoid offense to a specific group in society. This is an issue that was discussed more than one time on TV screens (mirror.co.uk). One of the scholars who explored this dimension in nursery rhymes is Nancy Larrick who accused nursery rhymes, and 
مجلة وادي النيل للاراسات والبحوث الإنسانية والاجتماعية والتربوية (مجلة علمية محكمة)

(ISSN : 2536 - 9555)

children's literature in general, of being exclusive of and humiliating to children of colour (Rogers).

This reading, thus, amalgamates the literary with nonliterary, so to speak, paraphernalia, i. e. the "large number of objects that... are connected with a particular activity" (collinsdictionary). Essential to this New Historicist reading of the poem is the consideration that, like other nursery poems in the canon, this poem is anonymous. The very idea of the anonymity of the rhymes adds to the concept of these poems being traditional and national heritage, "our Heritage is conveyed in Nursery Rhymes" (rhymes.org).

Together with the simplicity of the rhyme above, and essential to this reading, is to notice the apparent naivety of the words and that they are adroitly employed to convey multi-layered content that is subtly concealed under the veil of naïvely simple lyricism of the song. Politics, it should be remembered, was considered a taboo at the time this nursery appeared. The critical approach applied is interested in "recovering lost histories and in exploring mechanisms of repression and subjugation" (purdue.edu). The subtle use of language is meant to satirise, and chronicle, the stagnant, tight situation English wool trade and industry underwent. It also exposes the hard conditions workers, and people in general, experienced during the time the poem appeared. The indirect way the poem exposes the deplorable milieu of the time serves two functions: it criticises the political orientations of the time and, at the same time, saves those who comment on the situation from being punished, mostly by being hanged or burnt at stake, because of interfering with politics.

"Jack Sprat" is another poem with important economic and political bearings. Though the poem was first published in 1744, in Tommy Thumb's Pretty Song Book, it existed orally long before that. The poem comments on the political, social and economic statuses of the time. Like "Baa, Baa Black Sheep", this poem has been differently interpreted. While some critics assert that Jack Sprat, of the poem, refers to King Richard I, others believe the name refers to Prince John, King Richard the Lionheart's brother. 


\section{A New Historicist Reading of Selected Children's Nursery Rhymes Dr. Mohammad Ahmad Mostafa Al-Leithy}

مجلة وادي النيل للار اسات والبحوث الإنسانية والاجتماعية والتربوية (مجلة علمية محكمة)

In accordance with one interpretation of the poem, "Jack Sprat" is King Charles I (1600-1649), son of King James VI of Scotland; and Joan who "ate all the fat" is his wife, Queen Henrietta Maria (1609-1669), daughter of King Henri IV of France and sister of King Louis XIII (csbsju.edu) who was known for her powerful political dominance (nga.gov). "Jack Sprat" stands for someone of authority who does not care about the welfare and prosperity of his people and causes his nation to suffer from poverty and destitute. Avoiding mentioning real names is a discrete political maneuver that helped save the necks of the authors and the singers of the lyric alike. This casts enough light on the relationship between the government and the people.

Some historians consider Jack Sprat to be political in nature. In this case, Jack Sprat and his wife are named for King Charles I and Queen Henrietta, who ruled England from 1625-1649. King Charles' reign was plagued with wars, financial problems, and mistrust. Parliament refused to fund the war efforts of the king leaving him "lean". When King Charles I angrily disbanded Parliament, Queen Henrietta imposed an illegal war tax to get some "fat" for the king's war chest.

Eventually, King Charles I became so unpopular that he was executed, ending rule by monarchy in England in 1649. (csbsju.edu)

An important consideration consists in the very choice of the name "Jack Sprat" which connotes lack of respect since the name is used derogatorily. As one writer comments, this name "is an old term referring to a thin, dwarf or "very little fellow." The rhyme can well conjure up the image of a married couple consisting of a man who is "a dwarf and a woman who is larger than average" (csbsju.edu). The name is, thus, meant to draw an image of a dwarf-like husband versus a giant-like wife, obese with the fats she 
devours. It is interesting to mention that some diet programs and companies have recently applied the name "Jack Sprat" to dietary systems and regimens due to the name's traditional suggestiveness of thinness (csbsju.edu):

\author{
Jack Sprat could eat no fat \\ His wife could eat no lean \\ And so betwixt the two of them \\ They licked the platter clean \\ Jack ate all the lean, \\ Joan ate all the fat. \\ The bone they picked it clean, \\ Then gave it to the cat (rhymes.org)
}

It is worth remarking that King Charles I was King of England, Scotland and Ireland from 1625 to 1649 when he was executed. His wife, Queen Henrietta, was not executed and this is referred to in the last two stanzas of the poem. Jack Sprat of the poem thought his wife died when she fell into the ditch but she did not drown as the ditch was dry. The dryness of the ditch can stand for the economic hardships England gone been through at these times:

Jack Sprat was wheeling, His wife by the ditch.

The barrow turned over, And in she did pitch.

Says Jack, "She'll be drowned!"

But Joan did reply,

"I don't think I shall,

For the ditch is quite dry." (rhymes.org)

Another possible interpretation of this poem is that Jack Sprat stands for Prince John, King Richard the Lionheart's brother, who imposed heavy taxes on the English people to collect the ransom required for setting King Richard Lionheart free. On the

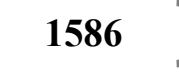




\section{A New Historicist Reading of Selected Children's Nursery Rhymes Dr. Mohammad Ahmad Mostafa Al-Leithy}

\section{مجلة وادي النيل للاراسات والبحوث الإنسانية والاجتماعية والتربوية (مجلة علمية محكمة)}

way back from a crusade, King Richard Lionheart was captured and taken as a hostage by Duke Leopold, the son of the Austrian duke Henry II, who asked for a huge ransom of 150,000 marks. Prince John collected the ransom from the English people who "had already paid lots of taxes to pay for Crusade", and he paid the ransom, and King Richard was freed but people in England were left in destitute (thedeanacademy.org).

It is worth noting that both King Richard I and Prince John led their country England to economic crises. The former declared war on Spain and, when the Parliament refused to support him financially, he dissolved the parliament. His wife, Henrietta Maria, his Queen, however was so audacious that she imposed heavy "illegal war taxes" on the people (publishing.cdlib). King Richard I always had problems with the parliament and this led to the English Civil War (1642-1651); and he was finally executed. S. Greenblatt dubs this authoritative abuse of power "state bureaucracy" (Lodge 497). The poem points out that at first the king was not encouraged to eat the fat but later on, after his wife took the lead, he got into the habit of eating fat, i. e. tax-collecting. Prince John, according to the other interpretation of the poem, imposed taxes on the people to set his brother free. In both cases, the taxes imposed left the people suffering from abject poverty.

One of the shortest and most important of all the nursery rhymes, the two-line verse "When Adam Delved", has proved profoundly influential. The word "delved" means worked. This fourteenth-century, short rhyme satirises the class system that has characterised the English society for many centuries. Class hierarchy in England is a politically and socially imposed system under the yoke of which the marginalised lower class had succumbed for centuries. The rhyme tells readers and listeners that people are equal and that classes were created by man, by aristocrats, to enslave poor fellow men. As Linda Alchin remarks, "this seemingly innocent rhyme was uttered and muttered by the peasants of the land" (81). Despite its simplicity, this poem led to a revolution: 


\section{مجلة وادي النيل للاراسات و البحوث الإنسانية والاجتماعية والتربوية (مجلة علمية محكمة)}

(ISSN : 2536 - 9555)

When Adam delved, and Eve span

Who was then a gentleman? (rhymes.org)

The rhyme became motto-like of an upcoming revolution at that time. This social protest rhyme strongly satirises and admonishes the idea of social classes, class segregation and such oppositions of master/servant, superior/inferior and the like; it reminds people they were equal, not masters and slaves.

This two-line political rhyme awakened in English citizens, especially peasants and craftspeople, a sense of their being as important in society as those of higher classes; they are, so to speak, the base of social structure and the "salt of the earth" (courant). The question was posed and an answer was required from the upper class. The rhyme's brevity and clarity add importantly to its endurance as well as the easy and rapid circulation of the lines. Of the eleven words that comprise the poem, nine words are monosyllabic and two are bi-syllabic. Further, the short vowels of the verse, the only exception being that in Eve, adds to the grim and serious tone of the rhyme. Absence of long vowels and diphthongs makes this rhyme, unlike many others, hard to sing. The peasants' realising of their essential existence as a powerful force in society led to a revolution, namely the English Peasant Revolt of 1381.

It is noteworthy that prior to that revolution, the English people had suffered for decades from abject poverty and diseases, foremost among these was the deadly Black Death (1346-1353) that came later to be known as Bubonic Plague, which added greatly to the misery and poverty of the English people. The plague killed one third of the English population (pnas.org). Lizzie Wade even says that it killed "about half of all Londoners" (science.org). As many historians assert, the plague "helped to fuel the fire which culminated in the Peasants Revolt" (rhymes.org). Such was a turning point in the history of England that enabled "peasants together, to demand more freedoms from their Lords" (bbc.co.uk).

By word of mouth, the rhyme spread among the illiterate majority of the English people at the time and led to radical social changes. Orality, it should be noted, is an outstanding feature of the 


\section{A New Historicist Reading of Selected Children's Nursery Rhymes Dr. Mohammad Ahmad Mostafa Al-Leithy}

مجلة وادي النيل للاراسات والبحوث الإنسانية والاجتماعية و التربوية (مجلة علمية محكمة)

rhymes. This has a lot to do with this New Historicist reading of the rhymes since these rhymes were originally composed and sung by commoners. Together with the orality of this tradition, national keenness on passing the tradition on from one generation to another asserts the importance of this tradition as a national heritage. Orality, as has been noted, means that ignorance dominated lower classes in the fourteenth century.

It is important to remember that most of these rhymes were originally sung by adults, not by children. Few critics are aware of this important fact. At times when the majority of people did not read or write, and when the written word was easily taken as an evidence of conviction and could easily cost one one's life, these simple lyrics were easy to memorise and sing by the common illiterate folks. This is vital to this New Historicist reading of the poems as it tells us that many of these rhymes were the verses of the illiterate Englishman (rhymes.org). The terse and succinct nature of these rhymes as well as their repetitive nature and lyricism suited the taste of the illiterate commoners and their times. Not less importantly, however, is that most of these poems are about authorities.

Many of these nursery rhymes, it is to be remembered, were written throughout the centuries that witnessed the highly sophisticated verses of G. Chaucer, E. Spenser, W. Shakespeare, J. Dryden, A. Pope, W. Wordsworth and A. Tennyson. The rhymes, then called poems, were, thus, composed in parallel with the lofty and highly polished poetic productions of such great writers but these rhymes were mostly out of the limelight and did not find their way to the press for centuries because of their socio-political satirism and, not less importantly, because these were, so to speak, the commoners' verses. In their essence, such were, more than anything else, satirical in nature. Indeed, a good number of the rhymes were composed to express the Englishman's worries about, protests against and satires of the political, the social, the economic and the religious issues of different times. They, thus, address issues that busied the mind of English marginalised poor folks rather than the learned or the well to do people in England. Many 
مجلة وادي النيل للاراسات والبحوث الإنسانية والاجتماعية والتربوية (مجلة علمية محكمة)

(ISSN : 2536 - 9555)

of the rhymes have to do with powerful authorities. Due to the fact that there were many taboos: religious, social, political and others, it was forbidden for the public, more than others in society, to talk about political affairs of their times, such subtle, simply delusive lyrics were devised to help poor folks express their fears, worries and cares, especially those of political concern.

The persistence of these rhymes and the fact that they could stand the test of time assert their being a genuine part of the British national tradition and memory. Even after the spread of literacy among the British, the rhymes persisted and continued to be a genuine part of the nation's oral tradition. Enduringly, these were passed from generation to another and, mainly, because of their lyricism and verbal simplicity they were sung by children and became part of children's literature. The rhymes, thus, came to be recognised as a constituent part of what is known today as children's literature (Maybin 205-9).

It is of great importance to say that the great writers of each age were themselves influenced by these rhymes and that influences of the rhymes seeped into their writings. To better understand the true value of the rhymes, as Dolezalova observes, we can find traces of many "nursery rhymes in literary works" (6). It is not difficult to identify the veins of such rhymes stretching and reverberating throughout the works and the words of a large number of men of letters including William Shakespeare (rhymes.org), Rudyard Kipling (kiplingsociety.co), Alexander Dumas (Kelsy). Robyn MacCallum's book Screen Adaptations and the Politics of Childhood: Transferring Children's Literature into Film gives many examples which show that works of literature teem with quotations from and allusions to nursery rhymes. In addition to men of letters, many important figures in different fields, including politics, were clearly influenced by nursery rhymes. To give few examples in this respect, the former American President Theodore Roosevelt (alzhn.ca), Political Cartoonist Clifford K. Berryman (jstor.org), Walt Disney's team of animators, non-fiction director and writer James Leasor, director of children's film "The Wizard of Oz" and author of the book titled The Plague 
A New Historicist Reading of Selected Children's Nursery Rhymes

Dr. Mohammad Ahmad Mostafa Al-Leithy

مجلة وادي النيل للاراسات والبحوث الإسانية والاجتماعية والتريوية (مجلة علمية محكمة)

and the Fire (1961) have revealed the influences such rhymes had on them.

On the fifth of November every year, England celebrates one of the biggest traditional events. The occasion has its origin in an event that took place more than four hundred years ago when, in 1605 Guy Fawkes, a York man, conspired with other men to explode the House of Parliament in London. The plot got known and the schemers were executed. The name Guy Fawkes is quite popular to the British (King). Celebrating the event started two years later, in 1607. Around 70,000 people, in different cities, take part in the celebrating the event annually. The reason behind Fawkes's plot is believed to be religious persecutions that Catholics of the time underwent:

Catholics were being persecuted and there were laws against them, all the Catholic priests were ejected from the country. Thirteen people including Guy Fawkes rented a house next door to Parliament to tunnel through to the cellars under the Parliament building. They put 36 barrels of gunpowder into the cellars to explode when the ... government arrived. Guy Fawkes was a believer in the traditional Catholic religion. He was British but he had been a soldier fighting for the Catholics against the Protestants in Holland. He returned to Britain and joined the group of militant Catholics ... (King)

Socially, the night of the festivity is known as the "Guy Fawkes

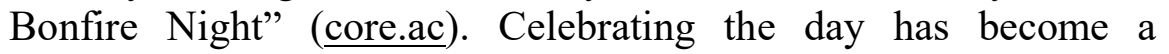
tradition that has continued throughout centuries. The celebration serves an important social and political function; it reminds people that "dissent would often be punishable by death!" (rhymes.org). People of different ages prepare for and take part in celebrating the event. They collect "old furniture, wood, paper and other rubbish to add to the bonfire. Every area of the village had their own bonfire and the groups of 20 to 50 children would compete to build the biggest and most spectacular bonfire" (King). 
مجلة وادي النيل للاراسات والبحوث الإنسانية والاجتماعية والتربوية (مجلة علمية محكمة)

(ISSN : 2536 - 9555)

In its original form, the poem had twenty-five lines and it revealed intolerance and advocated violence against Catholics. That is why the lines have been shortened in England to its current form:

Remember Remember

"Remember remember the fifth of November Gunpowder, treason and plot.

I see no reason why gunpowder, treason

Should ever be forgot..." (rhymes.org)

The skipping of the majority of the lines of this poem is meant to avoid provoking feelings of hatred and religious fanaticism among adherents of Catholicism and Protestantism.

Towering above all others in nursery rhymes are the figures of King Henry VIII (1491-1547) and his daughter Queen Mary (1516-1558). The former's name has been associated with religious persecution, lasciviousness and lust, the latter's with blood and religious persecution. The poems "Goosey, Goosey Gander" and "Ring Around the Rosy" can speak volumes of the important events that charaterised that era when King Henry VIII broke with the Roman Church and how that "brought the danger of invasion from Catholic Europe. But the money plundered from the monasteries was put towards building a system of coastal artillery forts (1538-47). Designed for heavy cannon, these reflected the triumph of firearms in warfare" (english-heritage). In her turn, Queen Mary I features prominently in a number of rhymes foremost among which are "Three Blind Mice", and "Goosey, Goosey Gander" and "Mary, Mary, Quite Contrary".

"Goosey, Goosey Grander" is a poem about religious persecution that was practiced at the hands of King Henry VIII (1491-1547) under whose rule Catholic priests underwent the worst of persecutions, torture and killing. To save their lives, they often hid in crypts, cellars and small, hidden rooms to avoid what was else an inevitable death. These spots came later to be called "priest holes" (researchgate.net/publication/2). 
A New Historicist Reading of Selected Children's Nursery Rhymes

Dr. Mohammad Ahmad Mostafa Al-Leithy

مجلة وادي النيل للاراسات والبحوث الإسانية والاجتماعية و التربوية (مجلة علمية محكمة)

Goosey, Goosey Gander where shall I wander, Upstairs, downstairs and in my lady's chamber

There I met an old man who wouldn't say his prayers, I took him by the left leg and threw him down the stairs. (rhymes.org)

More than all else, two great events of King Henry VIII's time are chronicled through and through in nursery rhymes: the Great Plague (1665-1666) and the Great Fire of London (1666). Each left its indelible scars on the memory of the nation as recorded in nursery rhymes. Peter Barry acknowledges that New Historicism's is concerned with powerful authorities in society as he asserts that New Historicists "focus attention... on issues of State power and how it is maintained ... on patriarchal structures and their perpetuation" (197).

"Ring Around the Rosy" poem chronicles one of the most important times in the history of England. The Great Plague of London, also referred to historically as Bubonic Plague and Black Death, is a pandemic that horribly spread in London in 1665 and took the lives of countless thousands at the time. "Ring Around the Rosy" is one of the poems that chronicles the event:

\begin{tabular}{|c|c|}
\hline Ring around the rosies & Ring-a-Ring o'Rosies \\
\hline A pocketful of posies & A pocket full of posies \\
\hline "Ashes, Ashes" & "A-tishoo! A-tishoo!" \\
\hline $\begin{array}{l}\text { We all fall down } \\
\text { rhymes.org) }\end{array}$ & We all \\
\hline
\end{tabular}

This poem is about one of the important events in the history of England when the plague spread all across the country. Significant to this reading of the poem is the fact that socially, the poor masses were ruthlessly victimised by the plague while high and middle 
مجلة وادي النيل للاراسات والبحوث الإسانية والاجتماعية والتريوية (مجلة علمية محكمة)

(ISSN : 2536 - 9555)

class citizens fled the city of London, that was horribly ravished by the pandemic, and some even fled England, to save their lives. Most of the poor citizens of London lost their jobs at the time since trade stopped with plagued London, and shortage of food and health supplies ensued. This has been authorised socially and historically:

Rats carried the fleas that caused the plague. They were attracted by city streets filled with rubbish and waste, especially in the poorest areas. Those who could, including most doctors, lawyers and merchants, fled the city. Charles II and his courtiers left in July for Hampton Court and then Oxford. Parliament was postponed and had to sit in October at Oxford, the increase of the plague being so dreadful. Court cases were also moved from Westminster to Oxford...All trade with London and other plague towns was stopped. The Council of Scotland declared that the border with England would be closed. There were to be no fairs or trade with other countries. This meant many people lost their jobs - from servants to shoemakers to those who worked on the River Thames. (nationalarchives.gov)

Streets reeked with the stench of rotting bodies which, a little time later was accompanied by another of the cremation of masses of bodies. Nothing in London at that time was more overwhelmingly looming than death that seemed to be forthcoming and lurking in every single house and on every corner of the streets. It was 


\section{A New Historicist Reading of Selected Children's Nursery Rhymes Dr. Mohammad Ahmad Mostafa Al-Leithy}

مجلة وادي النيل للار اسات والبحوث الإنسانية والاجتماعية والتربوية (مجلة علمية محكمة)

experienced as no other thing at the time. It was heard through the violent sneezing as well as through the painful groans and cries of those dying, felt through the fevered bodies, smelt through the ashes, cremations as well as through the countless stinking corpses and seen through the bodies that dropped all through the streets and the lanes. In 1966, the Great Fire of London broke out. it burnt a vast number of houses and churches and left thousands of people homeless. It was this very incident, however, that put an end to the spread of the pandemic by burning the rats that spread the plague.

"Mary, Mary, Quite Contrary" stands out as one of the most important of political and religious nursery rhymes. "Contrary" of the title is meant to oppose Queen Mary with Virgin Mary, Christ's mother. The former and the latter are seen as poles apart. The former's assumed religious intolerance and bloodiness are meant to contradict sharply with the latter's tolerance and meekness. Specifically speaking, this poem is taken to bear direct reference to Queen Mary Tudor, daughter of King Henry VIII. A staunch and arduously fanatic Catholic, she persecuted English Protestants, especially Protestant priests, at her time. More than anything else, her torturing, execution and religious persecution of the Protestants, stigmatised her reign. The fear of English Protestants greatly augmented as they saw such trials to be another form of the the Spanish inquisition, "Another form of execution during Mary's reign was being burnt at the stake - a terrible punishment much used during the Spanish Inquisition." (books.google):

Mary, Mary quite contrary, How does your garden grow?

With silver bells and cockle shells

And pretty maids all in a row. (rhymes.org) 
مجلة وادي النيل للاراسات والبحوث الإنسانية والاجتماعية والتربوية (مجلة علمية محكمة)

(ISSN : 2536 - 9555)

This is one of few political poems that mentions a queen by her name. Ironically, the "garden" that grow suggest the idea that even though Queen Mary was an ardent enemy of Protestants and Protestantism, her persecutive and bloody practices would not succeed in rooting out Protestantism from England. The phrase "silver bells" stand for Catholicism, Catholic cathedrals and Catholic rituals that prospered at her time. The "bells" are also believed to symbolise scaffolds that were used as "instruments of torture (silver bells) and execution by burning them alive at the stake" (rhymes.org). Some critics believe the question, "How does your garden grow" to imply the idea of lack of an heir to the English throne. The "row" in the poem can refer to the multitudes of Protestants executed under Queen Mary's reign. This is supported by the idea that "the Maiden" was commonly used to refer to the guillotine at the time. The word Maiden was shortened to Maids, Maiden - shortened to Maids in the "Mary, Mary" Nursery Rhyme (rhymes.org):

Three blind mice, three blind mice,

See how they run, see how they run,

They all ran after the farmer's wife,

Who cut off their tails with a carving knife,

Did you ever see such a thing in your life,

As three blind mice? (rhymes.org)

As one historian observes, "[t]oday Britain is a country where religion is not very important in political life. However, in [the past] your religion was very important and your life could depend on your religious beliefs" (King). The rhyme above, as many critics believe, refers to three Protestant priests who, at Queen Mary's time, stuck firmly to their Protestant beliefs and refused to renounce their belief despite the ruthless religious persecutions practiced against Protestants at the time. The three were killed. They are commonly referred to as Oxford Martyrs:

In March 1554, all three men were imprisoned in the Bocardo Prison near Oxford's north gate. On April 14 , the men were taken from the Bocardo to the 
A New Historicist Reading of Selected Children's Nursery Rhymes

Dr. Mohammad Ahmad Mostafa Al-Leithy

مجلة وادي النيل للار اسات و البحوث الإنسانية والاجتماعية والتربوية (مجلة علمية محكمة)

University Church, St. Mary the Virgin, to prepare to dispute transubstination and the sacrifice of the mass....four days after the disputation, the outcome of which is easily guessed, all three men were brought before the commissioners and each was told he had been proved wrong and was given opportunity to recant. Each refused. They were condemned as heretics... they begged for permission to reply but were denied. (Hegg)

"Oranges and Lemons" is a popular nursery rhyme that dates as far back as 1744; it was first published in "Pretty Song Book" by Tommy Thumb. Ostensibly, the song celebrates London's different churches and their bells. Children usually play when they sing this rhyme. This song is believed to have its origin in some of the worst and most horrific events of violence in the history of England. The poem reads:

Oranges and lemons

Say the bells of St Clement's

You owe me five farthings

Say the bells of St Martin's

When will you pay me?

Say the bells of Old Bailey

When I grow rich

Say the bells of Shoreditch

And when will that be?

Say the bells of Stepney

Oh I do not know

Say the great bells of Bow

Here comes a candle

To light you to bed

And here comes a chopper

To chop off your head (mfiles.co.uk)

The poem is covertly critical of the how men of religion have become wholeheartedly involved in financial, worldly matters. Satirically, the song mentions the names of a number of the most important churches in London and shows how they are all 
مجلة وادي النيل للاراسات والبحوث الإنسانية والاجتماعية والتربوية (مجلة علمية محكمة)

(ISSN : 2536 - 9555)

concerned with money, owing and debts paying. The spirituality of religion, as the poem implies, has almost disappeared since men of religion, who toll the bells, have been caring only for money. The bells tolled at churches are not, as they used to be, to announce masses and other religious rituals and ceremonies, rather, they are tolled now for financial deals and transactions. Money spoils the pure spirituality of religion. In his Bible, Matthew says Jesus told his disciples, "If anyone would come after me, let him deny himself and take up his cross and follow me"

(esv.org/Matthew).The bond that relates all churches of London, as suggested by the poem, is now secular rather than religious.

Since a New Historicist reading pays enough attention to original manuscripts and publishing information of texts as well as pre-publishing modifying of texts and the reasons behind such modifications, it is appropriate here to mention that the poem "Oranges and Lemons" had a longer version that critically exposed some evil practices of the churches at the time the poem appeared. These practices included torturing and killing . one example from the older version of this poem that can support this point is, "Pokers and tongs say the bells of St. Johns". Many critics believe that the line refers to hideous ways of torturing that took place inside churches.

It is in the light that W. Blake's two poems "The Chimney Sweeper" and "The Garden of Love", written around the same period of time, can be understood, even though they were written around a century later. The first of Blake's poems above, exposing men of religion's abuse of children, was published in the poet's collection Songs of Innocence, in 1789, the second, exposing religion's encroaching on childhood amusement, was published in Blake's volume Songs of Experience in1794. Lines that were scathingly satirical of churches and men of religion, as the line quoted above, were deliberately left out by publishers of newer generations, probably under censorship and to prevent religious fanaticism. The original title was "London Bells".

Nursery rhymes can be said to fashion the personality of British children more than all else; they demarcate and shape the 


\section{A New Historicist Reading of Selected Children's Nursery Rhymes Dr. Mohammad Ahmad Mostafa Al-Leithy}

مجلة وادي النيل للار اسات والبحوث الإنسانية والاجتماعية والتربوية (مجلة علمية محكمة)

vision of a British child and crystalise his or her outlook on the future. As Marsh says, "one can relate the individual experiences of children to the wider macro-structures of society which shape their lives" (11).

\section{Conclusion}

To conclude, this paper has explored the multifacetedness of nursery rhymes which inseparably unveil the spirits of times that produced them. The New Historicist approach has been applied in coming to grips with the poems to explore the different aspects of the rhymes and the times they represent, whether these be personal, social, political, religious or economic. Nursery rhymes should be reassessed on the bases of their literary value. They are essential to the memory of the British nation. They are the storehouse of countless invaluable notions worth exploring and investigating. Even though these rhymes are often slighted and considered nonsensical, they are of great importance.

Nursery rhymes are a literary tradition that tells a micronarrative of the British nation. One of the important conclusions this paper has come up with is that many of the rhymes were commoners' verses. Such are the speaking memory of a longstanding nation. Originally, the rhymes were composed and sung by adults. This is a tradition that is keenly passed on and bequeathed from one generation to another.

New Historicists look at a text as a mosaic built up of bits and pieces; i. e. of personal, social, political, religious, among other elements, that elementally contribute to the constructing of a literary text. A text, in its turn, is an honest production of its milieu. Ostensible simplicity and naivety of a text, guises under which weighty ideas are expressed, can well be requirements of certain times to avoid certain taboos that would incur punishment. In their essence, many of the rhymes are satires. Overlooking such considerations would surely strip a work off much of its literary value since these elements contribute to the making of a text. Such, so to speak, mechanisms and biometrics of the times interfere 


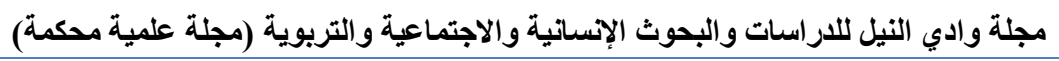

importantly with the very processes of creating and producing of a literary text.

Further investigations of the different aspects of the nursery rhymes is recommended to probe the veins of nursery rhymes that permeate and reverberate throughout the English literary tradition. Such a research has attempted to help relocate nursery rhymes on the map of the English literary canon.

Alchin, Linda.

\section{Works Cited}

https://www.google.com/search? $q=$ The + Secret + History + of + Nurs ery + Rhymes. $+2013 .+$ https $\% 3 A \% 2 F \% 2 F b o o k s$.google. Accessed on 14-6-2021.

alzhn.ca/wp-content/uploads/2020/04/April-Trivia.pdf. Accessed on 21-1-2021.

American Heritage Dictionary of the English Language, The. New York: Houghton Mifflin Company, 1992.

archive.org/stream/in.ernet.dli.2015.75797/2015.75797.The-RealPersonages-Of-Mother-Goose djvu.txt. Accessed on 5-112018.

Baldick, Chris. Oxford Dictionary of Literary Terms. New York: OUP, 2008.

Barry, Peter. Beginning Theory: An Introduction to Literary and Cultural Theory. Manchester: Manchester University Press, 2002.

bbc.co.uk/bitesize/guides/z2c2pv4/revision/1

books.google.com.sa/books?id=a7PImT0UwcYC\&pg=PA21\&lpg $=$ PA21\&dq.\&source $=$ bl\&ots $=2$ RnofvlD1g\&sig $=$ ACfU3U 1

UBzYzFKPglAxs9ZDjzkovvpGlzQ. Accessed on 28-82018.

Children's Literature. United Kingdom: The Open University, 2009.

Children's Voices in Contemporary Australia. https://historyofemotions.org.au/media/258576/cvcaprogram.pdf, 2016. 


\title{
A New Historicist Reading of Selected Children's Nursery Rhymes \\ Dr. Mohammad Ahmad Mostafa Al-Leithy
}

\author{
مجلة وادي النيل للار اسات والبحوث الإنسانية والاجتماعية والتريوية (مجلة علمية محكمة)
}

cla.purdue.edu/academic/english/theory/newhistoricism/modules/in troduction.html. Accessed on 4-4-2021.

collinsdictionary.com/dictionary/english/paraphernalia. Accessed on 12-9-2021.

core.ac.uk/download/pdf/235860247.pdf. Accessed on 2-8-2021.

courant.com/ctnow/hc-fea-word-watch-1125-story.html. Accessed on 23-1-2021.

csbsju.edu/Documents/Fine\%20Arts/education/Jack\%20Sprat\%20

Study\%20Guide.pdf. Accessed on 11-8-2019.

ddceutkal.ac.in/Syllabus/MA_English/Paper_08.pdf

Dolezalova, Hana. A Comparison of Czech and English Nursery Rhymes, 2008.

english-heritage.org.uk/learn/story-of-england/tudors/. 22-10-2018 esv.org/Matthew+10:38;Matthew+16:24;Mark+8:34;Luke+9:23;L uke+14:27/. 6-8-2020

Felluga, Dino. "General Introduction to New Historicism." Introductory Guide to Critical Theory.

Hawthorn, Jeremy. A Glossary of Contemporary Literary Theory. London: Arnold, 2000.

Hegg, David W. Reformation \& Revival. A Quarterly Journal for Church and Leadership, Volume 7, Number 1, Winter 1998. jstor.org/stable/29780870

Kelsy, Atiqa. "Nursery Rhymes and the History Behind Them". 2016.

researchgate.net/publication/305643790_Nursery_Rhymes and the History Behind Them. 26-3-2019.

researchgate.net/publication/297465173 Recusant_catholic_spaces in early_modern_England. 19-7-2020

King, David. http://www.esvilela.pt/euroots/docs/guyfawkes.pdf. 14-8-2021.

kiplingsociety.co.uk/rg nursery rhymes1.htm. 23-9-2021.

Langrish, Frank. British Sheep and Wool: A Guide to British Sheep Breeds and their Unique Wool. London: British Wool Marketing Board, 2010.

Lodge, David (ed.). Modern Criticism and Theory: A Reader. Edinburgh: Pearson, 2000. 


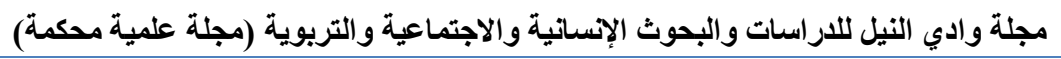

MacCallum, Robyn. Screen Adaptations and the Politics of Childhood: Transferring Children's Literature into Film. Sidney: Palgrave, 2018.

Maiti, Abhik and Naskar Deep. Of Deception and Dogma: The Delusive History Behind Nursery Rhymes, 2017.

Marsh, Jackie. Childhood, Culture and Creativity: A Literature Review. Newcastle, Sandyford. 2010.

mfiles.co.uk/scores/oranges-and-lemons.htm. 19-8-2021

mirror.co.uk/news/uk-news/toy-maker-changes-baa-baa-13705453. 3$8-2020$

mothergeek.co.uk/lifestyle/my-journal/2012/09/politically-correctnursery-rhymes/. 3-8-2021

nga.gov/collection/art-object-page.41651.html. 11-12-2020.

oxfordbibliographies.com/view/document/obo-9780199791231/obo9780199791231-0124.xml. 4-3-2021

parliament.uk/documents/commons-information-office/g08.pdf. 8-52021.

parliament.uk/globalassets/documents/commons-informationoffice/g08.pdf. 26-7-2021

pnas.org/content/pnas/115/6/1304.full.pdf. 1-4-2020.

publishing.cdlib.org/ucpressebooks/view?docId=ft9v19p2p6\&chunk.i $\mathrm{d}=\mathrm{d} 0 \mathrm{e} 3680 \&$ toc. depth $=1 \&$ toc $. \mathrm{id}=\mathrm{d} 0 \mathrm{e} 3176 \&$ brand $=$ ucpress. 12-8-2021.

purdue.edu/guidetotheory/newhistoricism/modules/introduction.html 23/3/2021. 6-3-2021

rhymes.org.uk/baa baa black_sheep.htm. 8-2-2020.

rhymes.org.uk/. 5-2-2018.

Rogers, Julia. Children's Literature: Special Collections from the special Collections of the Julia Rogers Liberary. goucher.edu/library/documents/Childrens_Lit.pdf

science.org/content/article/black-death-fatal-flu-past-pandemicsshow-why-people-margins-suffer-most. 1-4-2020.

Teng, Yu-chen. Analysis of Songs and Rhymes in Children English Textbooks, A thesis 2013.

thedeanacademy.org/wp-content/uploads/2019/10/History-RichardJohn-Knowledge-Organiser.pdf. 9-6-2020.

Thomas, Katherine E. The Real Personages of Mother Goose. Boston: Lothrop, Lee \& Shepard,1930. 